\title{
Probability of beef tenderness in confined cows - a meta-analytic approach
}

\section{Probabilidade de maciez na carne de vacas confinadas - abordagem meta-analítica}

\author{
Rangel Fernandes Pacheco ${ }^{1 *}$; Dari Celestino Alves Filho²; Jonatas Cattelam³; \\ Andrei Retamoso Mayer ${ }^{4}$; Mauren Burin ${ }^{5}$; Lucas Braido Pereira ${ }^{6}$; Sander Martinho \\ Adams $^{5}$; Ivan Luiz Brondani²
}

\begin{abstract}
This study aimed to assess the probability of meat tenderness in confined cows. For this purpose, CAPES and SciELO platforms were searched for papers under this subject published in Brazil between 2000 and 2015. A total of 43 articles were found, of which eleven were used. Those selected approached the finishing of confined cows and specified animal genetic group, breed, and age at experiment start. Moreover, all these studies evaluated sensory and organoleptic characteristics of meat, following the same method. Each variable was analyzed by logistic regression, using the LOGISTIC procedure of SAS. The factors were evaluated by odds ratio (OR), in which changes in the probability of meat tenderness were estimated by means of an add-on function in regression variable units. Animal age at the beginning of termination, percentages of zebuine blood and heterozygosity, and marbling score are factors that affect $(p<0.30)$ the chance of beef tenderness. The probabilities of obtaining a tender meat increase when age at termination beginning and zebuine genotype participation are reduced, as well as when heterozygosity (via crosses) and meat marbling score increases.
\end{abstract}

Key words: Heterozygosity. Logistic regression. Meta-analysis. Odds ratio. Panel of evaluators.

\section{Resumo}

Objetivou-se avaliar a probabilidade de maciez da carne de vacas confinadas. Para isso foram avaliados todos os artigos publicados no Brasil entre os anos de 2000 a 2015 com acesso via plataforma CAPES e SciELO. Ao total foram localizados 43 artigos dos quais foram utilizados onze, que envolveram a terminação de vacas em confinamento; além de informar o grupo genético e raça dos animais, a idade das vacas ao início do período experimental e que tivessem estudado características sensoriais e organolépticas da carne seguindo a mesma metodologia. Para análise de cada variável foi utilizada a regressão logística, por meio do procedimento LOGISTIC, disponível no SAS. Os parâmetros foram

\footnotetext{
1 Prof., EBTT, Instituto Federal de Santa Catarina, IFSC, Câmpus Canoinhas, Canoinhas, SC, Brasil. E-mail: rangelzootec@, hotmail.com

2 Profs., Departamento de Zootecnia, Universidade Federal de Santa Maria, UFSM, Santa Maria, RS, Brasil. E-mail: darialvesfilho@ hotmail.com; ivanbrondani@gmail.com

3 Prof., Universidade Federal Fronteira Sul, UFFS, Câmpus Realeza, Realeza, PR, Brasil. E-mail: jonatascattelam@yahoo.com.br

4 Prof., Instituto de Desenvolvimento Educacional de Passo Fundo, IDEAU, Passo Fundo, RS, Brasil. E-mail: andreirm@bol.com.br

5 Discentes, Curso de Mestrado do Programa de Pós-Graduação em Zootecnia, UFSM, Santa Maria, RS, Brasil. E-mail: maurenburin@hotmail.com; sander.adams@hotmail.com

6 Discente, Curso de Doutorado do Programa de Pós-Graduação em Zootecnia, UFSM, Santa Maria, RS, Brasil. E-mail: braidopereira@gmail.com

* Author for correspondence
} 
avaliados pela estatística de razão de chances (odds ratio), em que a mudança nas chances de maciez foi estimada a partir da função de acréscimos nas unidades das variáveis regressoras. A idade em que as vacas iniciam a terminação, assim como o percentual de sangue zebuíno e heterozigose juntamente com o marmoreio são fatores que afetam $(p<0,30)$ a chance de maciez da carne das vacas. Reduzir a idade ao início da terminação e a participação de zebuíno no genótipo das vacas, aliado a aumento na heterozigose por meio de cruzamentos e incremento no marmoreio da carne, aumenta a probabilidade de vacas de descarte demonstrarem carne macia.

Palavras-chave: Heterozigose. Metanálise. Painel de avaliadores. Razão de chance. Regressão logística.

\section{Introduction}

Production system characteristics and carcass or meat traits are generally used to set prices for beef purchases. In a large number of studies focused on animal science, quantifying these measurable factors is restricted to correlating variables individually, without considering their interactions.

Meta-analytic procedures using multivariate statistics can help to better understand how production system features and carcass and meat quality influence beef tenderness. In addition, the decision-making about the use of technologies in the production phase, still at the farm level, can be aided for a sample increase and identification of the effects and potential trends undetectable in experiments.

Among the generalized linear models, logistics regression has been used in several areas of knowledge. This is because, from a mathematical point of view, it is easy to use and presents a rich and direct interpretation of results, besides allowing the evaluation of coefficients by means of odds ratio testing (HOSMER et al., 2013). In addition to these procedures, the proportion of each factor effect on beef tenderness is relevant to determine its importance on this characteristic, which is of the greatest interest to consumers.

By adapting these procedures, a powerful tool is created for predictions about meat tenderness. Given this, the present study aimed to evaluate the probability of beef tenderness in cows at culling and estimate the proportion of the effect of independent variables on this trait, using a compilation of articles published in Brazil between the years of 2000 to 2015 that evaluated the quality of beef meat.

\section{Material and Methods}

We retrieved papers that dealt with studies carried out in Brazil regarding carcass and discard meat evaluations. Only studies published between 2000 and 2015 in the SciELO and Capes research platforms were assessed. These papers were accessed online, using a combination of the following keywords: carcass, meat, female bovines, heifers, and cows. A total of 43 articles were found.

To be incorporated into database, the papers had to meet the following terms: (1) animals had to be finished in feedlot, (2) provide information on animal genetic group and breed, (3) inform animal age at termination start, and (4) have a meat tenderness evaluation made by panel of evaluators, following the method for sensory and organoleptic traits described by Metz et al. (2009).

Each treatment in the papers was considered as a database unit, from which some information was drawn. From Material and Methods section, we extracted data on termination period and roughage: concentrate ratio. From Results and Discussion sections, we gathered information on carcass traits such as average subcutaneous fat thickness and slaughter weight, and on meat treats such as coloration, marbling level, texture, juiciness, and palatability. Genetic effects were estimated by calculating individual heterozygosity and prevalence of zebu genotypes. Table 1 lists the papers that composed the database of this study. 
As observed in Table 1, eleven articles met the requirements for composing the database. In all studies, carcasses were split in half after cooling. On the right cold half carcass, a cut was made between the $12^{\text {th }}$ and $13^{\text {th }}$ ribs, so that Longissimus dorsi muscle was exposed for subjective scoring for color $(1=$ dark red and $5=$ lively red $)$, texture $(1=$ very coarse and $5=$ very fine), and marbling level $(1$ to $3=$ traces, 4 to $6=$ light, 7 to $9=$ little, 10 to $12=$ average, 13 to $15=$ moderate; 16 to 18
$=$ abundant). Samples of Longissimus dorsi muscle were packed in plastic film and wrapped with brown paper, identified, and frozen for later organoleptic analyses. Also, 2.5-cm thick stakes were extracted and cooked until internal temperature reached $70^{\circ} \mathrm{C}$. Then, a panel of tasters made subjective analyses regarding tenderness $(1=$ very hard and 9 $=$ extremely tender $)$, palatability $(1=$ no taste and 9 $=$ extremely tasty $)$, and juiciness $(1=$ no juiciness and $9=$ extremely juicy) by chewing (Panel).

Table 1. Papers selected to compose the database with respective information on the tested effect, number of treatments, and number of evaluated animals

\begin{tabular}{|c|c|c|c|}
\hline Paper & Tested effect & $\mathrm{N}^{\mathrm{o}}$ treat. & $\mathrm{n}$ \\
\hline Cattelam et al. (2009)'; Ferreira et al. (2009) $)^{1}$ & Genetic group & 2 & 12 \\
\hline Kuss et al. $(2005 a, b)^{1}$ & Genetic group & 4 & 24 \\
\hline Marques et al. (2006) & Anestrous & 3 & 19 \\
\hline Moura et al. (2013) & Concentrate Level & 2 & 20 \\
\hline Restle et al. (2001) & Genetic group & 2 & 25 \\
\hline Restle et al. $(2002 a, b)^{1}$ & Genetic group & 4 & 45 \\
\hline Restle et al. (2003) & Genetic group & 3 & 25 \\
\hline Vaz et al. (2002) & Animal category & 1 & 12 \\
\hline Total & - & 21 & 182 \\
\hline
\end{tabular}

${ }^{1}$ Complementary study.

For the purpose of analysis, meat was considered tender if the values were above 6 points, and tough if they were below that.

The data underwent a logistic regression testing by the LOGISTIC procedure of SAS. The regression variables tested were: paper effect, animal age, subcutaneous fat thickness, genetic group, percentage of zebu breed in genotypes, individual heterozygosity, percentage of roughage in diet, finishing period, as well as meat marbling, coloration, texture, juiciness, and palatability.

Several multiple regression models with linear and quadratic effects were tested using a stepwise procedure at 0.25 level to enter and 0.30 to remain in the model, respectively (HOSMER et al., 2013). The best fit model was chosen by the Hosmer and Lemeshow test for fit quality.

After fitting the model $(\beta \mathrm{i}>\mathrm{s}$ parameter estimation), the quality of the fit model and the individual significance of the set of parameters of the model were tested using a likelihood ratio test at $5 \%$ significance.

The best calculated multiple regression model for the probability of the $i^{\text {th }}$ cow presenting tender meat and being considered for data analysis is described by:

$$
\ln \left(\frac{p_{i j k l m n o}}{1-p_{i j k l m n o}}\right)=\beta_{0}+\beta_{1} x_{1 i}+\beta_{2} x_{2 j}+\beta_{3} x_{3 k}+\beta_{4} x_{4 l}+\beta_{5} x_{5 m}+\beta_{6} x_{6 n}+\varepsilon_{i j k l m n o}
$$


Wherein: pijklmn is the probability of obtaining tenderness, $X_{1 i}$ is the effect of the article, $X_{2 j}$ is the animal age at the beginning of termination, $X_{3 k}$ is the zebu breed percentage in the genotype, $X_{4 l}$ is the heterozygosity, $X_{5 m}$ is the marbling score, $X_{6 n}$ is the termination period, $\beta(0,1,2,3,5$, and 6$)$ are the regression coefficients of the regression variables $X h$, and cijklmn is the random error associated with each observation.

An inconsistency test $\left(\mathrm{I}^{2}\right)$ was used to quantify the degree of heteroscedasticity in the data, which defines the variability percentage in effect estimates that is due to heterogeneity rather than to chance (SOUZA; RIBEIRO, 2009). The effect of each regression variable of the Logistic Regression model was measured by the coefficient of partial and total determination $\left(\mathrm{R}^{2}\right)$ obtained by the stepwise statistic. These coefficients were interpreted using the odds ratio (OR), which was estimated by the equation: $\mathrm{OR}=\exp$ (bk). This is the ratio between two potential results, i.e., the probability of success $(\pi \mathrm{j})$ and failure $(1-\pi j)$ in obtaining tender meat. These ORs were based on the average denominator of the data set for each model. The regression variable change units were: 10 months for cow age, $10 \%$ for zebuine breed percentage, $10 \%$ for heterozygous percentage, and 1 point for marbling score.

\section{Results}

Besides each article effect, the variables that composed the logistic regression model for beef tenderness were animal age, zebu breed percentage in genotype, individual heterozygosity, termination period, and meat marbling score (Table 2). These six factors could explain $65 \%$ of the variance in meat tenderness (Table 3). Given the subjective nature of this trait, our result is relevant considering the range of surveyed studies and number of variables considered (15 years of publications).

The study effect, or isolated article effect, was significant at $9 \%$ on the variation of this qualitative characteristic, which is of greatest interest to consumers. The inconsistency index $\left(\mathrm{I}^{2}\right)$, which evaluated the degree of heteroscedasticity on beef tenderness, showed no substantial heteroskedasticity among studies (46.8\%).

The average age of cows was 70.8 months, i.e., around six years. The standard deviation and the maximum and minimum values demonstrate the wide range of this variable in the studied articles. The result of partial $\mathrm{R}^{2}$ showed that animal age had an effect of $17.9 \%$ on this characteristic of the meat.

Table 2. Characteristics of the data used to develop the logistic regression model for the probability of beef tenderness.

\begin{tabular}{lccccc}
\hline \multicolumn{1}{c}{ Factor } & $\mathrm{N}$ & Average & Standard-deviation & Minimum & Maximum \\
\hline Tenderness by panel scores & 21 & 6.0 & 0.7 & 4.1 & 7.3 \\
Age, in months & 21 & 70.8 & 30.9 & 18 & 102 \\
Proportion of zebuine breed, in \% & 21 & 36.1 & 28.4 & 0 & 100 \\
Heterozygosity, in \% & 21 & 64.7 & 39.1 & 0 & 100 \\
Termination period, in days & 21 & 89.5 & 15.4 & 63 & 112 \\
Marbling score, in points & 21 & 6.1 & 0.5 & 4.7 & 6.9 \\
\hline
\end{tabular}

Zebu breeds represented only $36.1 \%$ of the cow genotypes. This result shows that most of the studies carried out in Brazil do not use genotypes that reflect the reality of production in the country. In this study, the trait zebuine breed percentage explained $12.7 \%$ of the variation in beef tenderness. About $80 \%$ of the herd in Brazil is composed by Zebu breeds, among which $90 \%$ is Nellore, given the greater adaptability of these breeds to the prevailing tropical climate in the country (SANTANA Jr. et al., 2016). 
Table 3. Total and partial coefficients of determination $\left(\mathrm{R}^{2}\right)$ for regression variables composing the logistic model for meat tenderness in slaughter beef cows.

\begin{tabular}{lcc}
\hline Factor & $\mathrm{R}^{2}-$ Partial & $\mathrm{R}^{2}$ - Total accumulated \\
\hline Animal age & 0.1790 & 0.1790 \\
Zebu breed proportion & 0.1275 & 0.3065 \\
Heterozygosity & 0.1204 & 0.4269 \\
Article & 0.0903 & 0.5172 \\
Marbling & 0.0887 & 0.6059 \\
Termination period & 0.0439 & 0.6498 \\
\hline
\end{tabular}

In the present study, heterozygosity had a value close to that of F5-generation genotypes from crosses between two different breeds (69\%). The effect of this characteristic on meat tenderness was of the order of $12 \%$. This factor is calculated and expressed in percentage, and it estimates the probability of alleles of a given locus coming from different breeds, thus assuming values ranging from 0 to $100 \%$ (PACHECO, 2016).
Termination period and marbling score were also significant for the logistic regression model. The effect of these factors on meat tenderness was 4.4 and $8.9 \%$, respectively. Based on the Hosmer and Lemeshow test, there is no evidence that the regression model was not well fit for the chance of beef tenderness ( $p=0.9002$ ) (Table 4$)$.

Table 4. Regression equation and probability estimate for the regression variables in evaluating meat tenderness of confined cows.

\begin{tabular}{lcccc}
\hline Tenderness & Parameter & Standard error & Odds ratio & HLT \\
\cline { 1 - 1 } Intercept & -1.6519 & 4.6382 & & 0.9002 \\
Product & -0.8945 & 0.5619 & & \\
Cow age & -0.1655 & 0.1361 & 0.191 & \\
Percentage of Zebu & -0.1425 & 0.0595 & 0.240 & \\
Heterozygosity & 0.0809 & 2.5706 & 2.245 & \\
Marbling & 3.0477 & 1.6247 & 21.066 & \\
\hline
\end{tabular}

HLT $=$ Hosmer and Lemeshow test.

As for the odds ratio, a 10-month increase was estimated for cow age at termination start in relation to the mean age (70.8 months). Thus, the chance of obtaining tender meat is expected to reduce in $80.9 \%$. A negative relationship was also observed for the percentage of Zebu breed in genotype, wherein for each $10 \%$ increase in this proportion, there was an estimated $76 \%$ reduction in the chance of meat tenderness.
Whereas $10 \%$ increase in heterozygous compared to $64.7 \%$ calculates an increase of 2.24 times the chance of obtaining tenderness meat. Also, a positive relationship with the marbling, wherein for each first point above 6.1 points is expected a 21 -fold increase in the chance of meat tenderness.

Although the termination period was significant $(p<0.3)$ to compose the logistic regression model, 
it did not enter the equation that explains the chance of meat tenderness, showing an average of 90 days, with a minimum of 63 and a maximum of 112 days.

\section{Discussion}

Our main objective was to identify factors affecting beef tenderness of culling cows, using measurable and/or observable variables in the production systems, and by carcass and meat characteristics. This proposal was based on the marketing importance of beef tenderness, since there are several factors related to its variation (GARMYN; MILLER, 2014).

Evaluating meat tenderness changes by quantifying other variables, or even defragmenting its influencing effects, is a procedure of analysis well known and employed in science. This approach comes from Newtonian and Cartesian mechanics and guides the basis of natural sciences. It seeks to understand the complexity of an event by breaking it down into factors, which can be further decomposed into new other factors until the minimum level, in order to understand how they act and their relationships.

Variables for a given model are selected by algorithm-based statistical procedures, which evaluates the importance of each variable to the model, being aligned to a decision rule that includes or excludes it from the model (AGRESTI, 2007). Conversely, a stepwise method, in linear models, uses F-test to select the variables for the model, using logistic regression; this is because the errors have a binomial distribution, thus significance is ensured by a likelihood ratio test. From a mathematical point of view, the more a variable generates a change in a likelihood logarithm, the greater its importance for the model (HOSMER et al., 2013).

The logistic regression showed that carcass traits were minor parameters for estimating the chance of obtaining tender meat if compared to genetic traits, animal age, and marbling scores. We chose the model for discussion based on the Hosmer and Lemeshow test. This test relates the data to its estimated probabilities, from the lowest to the highest ones, followed by a chi-square test to determine whether the estimated frequencies are close to those observed. So, the closer to 1 , the better the fit of the model to the data (HOSMER et al., 2013).

The effect of the article on tenderness results was significant, as observed in the ratio of effect and logistic regression, but without substantial heteroscedasticity. Thus, we did not have to adjust or remove any of the studies. Rotta et al. (2012) suggested that the inconsistency index is an important way of quantifying the heteroskedasticity of meta-analysis so that values above 0.50 can be considered high heteroskedasticity and require interventions.

As expected, cow age at termination beginning had a negative influence on the chances of obtaining meat tenderness and was the variable with the highest proportion of effect. This result can be related to the properties of muscle fibers (LEPETIT, 2008; PATTEN et al., 2008). With advancing age, these fibers can be modulated from FOG fibers (fast twitch fibers, oxidative-glycolytic metabolism, and intermediate color) and FG (fast twitch fibers, glycolytic metabolism, and white color) to SO fibers (slow twitch fibers, oxidative metabolism and red color), setting fewer tenderness features to the cow meat. Another significant point is the solubilization of collagen, which also decreases with advancing age, making the meat tougher (JURIE et al., 2006; GALLI et al., 2008; WEBER et al., 2013).

In general, cow meat has less acceptance at a retail level, what consequently impacts the other segments of the bovine production chain. This trend is mainly associated with the lower tenderness of this meat, which in turn, is jeopardized by age effect, as seen in our study. Livestock management practices, such as confinement, and meat maturation procedures are strategies aimed at minimizing this age effect (ROSE et al., 2010). 
The percentage of Zebu 'blood' showed a negative effect on the chance of met tenderness. Numerous studies have widely documented and supported this effect (CROUSE et al., 1989; LAGE et al., 2012; PACHECO et al., 2015). The main explanation for this is the action of enzymes linked to myofibrillar proteolysis during rigor mortis, called calpamine and calpastatin, since the relationship between them, in zebuine animals, decreases meat tenderness (CASAS et al., 2006; DUARTE et al., 2013; TIZIOTO et al., 2014). This effect is related to the frequency of certain genes responsible for meat tenderness depreciation and to a strong additive genetic effect in zebuine breeds for this feature (CASAS et al., 2006; SILVA et al., 2016).

By contrast, heterozygosity showed a positive effect on meat tenderness probability, with the same proportion as that of zebuine breed on the response variable. This result demonstrates that including animals of taurine origin in crosses of Brazilian herds may be an alternative to increase the qualitative variable of beef. It has also been recommended in Asian countries with low commercial competitiveness in the beef chain and herds with high participation of zebu 'blood'. In recent years, these issues have been discussed in order to improve the local bovine chain, through the exploration of heterosis from crosses (CHAIWANG et al., 2014). A model proposed by Koger et al. (1975) have shown linearity between heterozygosis and heterosis, such phenomenon has been widely identified, explored, and documented in various production systems. For the characteristic tenderness, Menezes et al. (2005) reported heterosis values of 11.63 and 10.80 in F2 and F3 generation steers from the crossing between Charolais and Nellore breeds, respectively.

An increasing beef marbling promotes a significant increase in the probability of obtaining tender meat. Although this variable contributed only $8 \%$ to explain the tenderness results by the effect probability analysis, it demonstrated a relevant role in the analysis of odds ratio. There is controversy as to the participation of marbling in beef tenderness, most of the studies have demonstrated the lack of influence on meat tenderness when measured by shear force. However, when measured by a panel of evaluators, this effect may be more representative, in view of the alteration of other organoleptic characteristics such as palatability and juiciness, contributing to a greater perception of meat tenderness when chewing, due to the stimulating effect of fat on salivation (OURY et al., 2009).

\section{Conclusions}

Reductions in animal age at slaughter and zebuine breed participation in genotypes, associated with increased heterozygosis values and meat marbling scores enhance the likelihood of obtaining meat tenderness.

\section{References}

AGRESTI, A. An introduction to categorical data analysis. $2^{\text {th }}$ ed. Hoboken: John Wiley \& Sons, 2007. 400 p.

CASAS, E.; WHITE, S. N.; WHEELER, T. L.; SHACKELFORD, S. D.; KOOHMARAIE, M.; RILEY, D. G.; CHASE JUNIOR, C. C.; JOHNSON, D. D.; SMITH, T. P. L. Effects of calpastatin and calpain markers in beef cattle on tenderness traits. Journal of Animal Science, Champaign, v. 84, n. 3, p. 520-525, 2006. DOI: $10.2527 / 2006.843520 x$

CATTELAM, J.; MENEZES, L. F. G.; FERREIRA, J. J.; RESTLE, J.; ARBOITTE, M. Z.; PAULA, P. C. Composição física da carcaça e qualidade da carne de novilhos e vacas de descarte de diferentes grupos genéticos submetidos a diferentes frequências de fornecimento de alimentação. Ciência Animal Brasileira, Goiânia, v. 10, n. 3, p. 764-775, 2009.

CHAIWANG, N.; JATURASITHA, S.; SRINGAM, K.; WICKE, M.; KREUZER, M. Comparison of the meat quality of thai indigenous Upland Cattle and F2crossbreds with $75 \%$ Charolais blood proportion. Journal of Applied Animal Research, v. 43, n. 2, p. 196-201, 2014. DOI: $10.1080 / 09712119.2014 .963087$

CROUSE, J. D.; CUNDIFF, L. V.; KOCH, R. M.; KOOHMARAIE, M.; SEIDEMAN, S. C. Comparisons of Bos indicus and Bos taurus inheritance for carcass 
beef characteristics and meat palatability. Journal of Animal Science, Champaign, v. 67, n. 10, p. 2661-2668, 1989. DOI: $10.2527 /$ jas $1989.67102661 x$

DUARTE, M. S.; GIONBELli, M. P.; PAUlinO, P. V. R.; SERÃO, N. V. L.; SILVA, L. H. P.; MEZZOMO, R.; DODSON, M. V.; DU, M.; BUSBOOM, J. R.; GUIMARÃES, S. E. F.; VALADARES FILHO, S. C. Effects of pregnancy and feeding level on carcass and meat quality traits of Nellore cows. Meat Science, Barking, v. 94, n. 1, p. 139-144, 2013. DOI: 10.1016/j. meatsci.2013.01.008

FERREIRA, J. J.; MENEZES, L. F. G.; RESTLE, J.; BRONDANI, I. L.; ALVES FILHO, D. C.; CALLEGARO, A. M. Características de carcaça de vacas de descarte e novilhos mestiços Charolês $\times$ Nelore em confinamento sob diferentes frequências de alimentação. Revista Brasileira de Zootecnia, Viçosa, MG, v. 38, n. 10, p. 1974-1982, 2009.

GALLI, I.; TEIRA, G.; PERLO, F.; BONATO, P.; TISOCCO, O.; MONJE, A.; VITTONE, S. Animal performance and meat quality in cull cows with early weaned calves in Argentina. Meat Science, Barking, v. 79, n. 3, p. 521-528, 2008. DOI: 10.1016/j. meatsci.2007.10.007

GARMYN, A. J.; MILLER, A. F. Meat science and muscle biology symposium - implant and beta agonist impacts on beef palatability. Journal of Animal Science, Champaign, v. 92 , n. 1, p. 10-20, 2014. DOI: $10.2527 /$ jas.2013-7097

HOSMER, D.; LEMESHOW, W. S.; STURDIVANT, R. X. Wiley series in probability and statistics. Applied logistic regression. $3^{\text {th }}$ ed. New York: John Wiley \& Sons, 2013. 510 p.

KOGER, M.; PEACOCK, F. M.; KIRK, W. G.; KIRK, W. G.; CROCKETT, J. R. Heterosis effects on weaning performance of Brahman-Shorthorn calves. Journal of Animal Science, Champaign, v. 40, n. 5, p. 826-833, 1975. DOI: $10.2527 /$ jas $1975.405826 x$

JURIE, C.; MARTIN, J. F.; LISTRAT, A.; JAILLER, R.; CULIOLI, J.; PICARD, B. Carcass and muscle characteristics of beef cull cows between 4 and 9 years of age. Journal of Animal Science, Champaign, v. 82, n. 3, p. 415-421, 2006. DOI: 10.1079/ASC200644

KUSS, F.; RESTLE, J.; BRONDANI, I. L.; ALVES FILHO, D. C.; PEROTTONI, J.; MISSIO, R. L.; AMARAL, G. A. Composição física da carcaça e qualidade da carne de vacas de descarte de diferentes grupos genéticos terminados em confinamento com distintos pesos. Revista Brasileira de Zootecnia, Viçosa, MG, v. 34, n. 4, p. 1285-1296, 2005a.
KUSS, F.; RESTLE, J.; BRONDANI, I. L.; PASCOAL, L. L.; MENEZES, L. F. G.; PAZDIORA, R. D.; FREITAS, L. S. Características da carcaça de vacas de descarte de diferentes grupos genéticos terminadas em confinamento com distintos pesos. Revista Brasileira de Zootecnia, Viçosa, MG, v. 34, n. 3, p. 915-925, 2005 b.

LAGE, J. F.; PAULINO, P. V. R.; VALADARES FILHO, S. C.; SOUZA, E. J. O.; DUARTE, M. S.; BENEDETI, P. D. B.; SOUZA, N. K. P.; COX, R. B. Influence of genetic type and level of concentrate in the finishing diet on carcass and meat quality traits in beef heifers. Meat Science, Barking, v. 90, n. 3, p. 770-774, 2012. DOI: 10.1016/j.meatsci.2011.11.012

LEPETIT, J. Collagen contribution to meat toughness: theoretical aspects. Meat Science, Champaign, v. 80, n. 4, p. 960-967, 2008.

MARQUES, J. A.; PRADO, I. N.; MOLLETA, J. L.; PRADO, I. M.; PRADO, J. M.; MACEDO, L. M. A.; SOUZA, N. E.; MATSUSHITA, M. Características físico-químicas da carcaça e da carne de novilhas submetidas a anestro cirúrgico ou mecânico terminadas em confinamento. Revista Brasileira de Zootecnia, Viçosa, MG, v. 35, n. 4, p. 1514-1522, 2006.

MENEZES, L. F. G.; RESTLE, J.; VAZ, F. N.; BRONDANI, I. L.; ALVES FILHO, D. C.; FREITAS, A. K.; METZ, P. A. M. Composição física da carcaça e qualidade da carne de novilhos de gerações avançadas do cruzamento alternado entre as raças charolês e nelore, terminados em confinamento. Revista Brasileira de Zootecnia, Viçosa, MG, v. 34, n. 3, p. 946-956, 2005.

METZ, P. A. M.; MENEZES, L. F. G.; ARBOITTE, M. Z.; BRONDANI, I. L.; RESTLE, J.; CALLEGARO, A. Influência do peso ao início da terminação sobre as características de carcaça e da carne de novilhos mestiços Nelore $\times$ Charolês. Revista Brasileira de Zootecnia, Viçosa, MG, v. 38, n. 2, p. 346-353, 2009.

MOURA, I. C. F.; KUSS, F.; MOLLETA, J. L.; PEROTTO, D.; STRACK, M. G.; MENEZES, L. F. G. Terminação em confinamento de vacas de descarte recebendo dietas com diferentes teores de concentrado. Semina: Ciências Agrárias, Londrina, v. 34, n. 1, p. 399408, 2013. DOI: 10.5433/1679-0359.2013v34n1p399

OURY, M. P.; PICARD, B.; BRIAND, M.; BLANQUET, J. P.; DUMONT, R. Interrelationships between meat quality traits, texture measurements and physicochemical characteristics of $\mathrm{M}$. rectus abdominis from Charolais heifers. Meat Science, Barking, v. 83, n. 2, p. 293-301, 2009. DOI: 10.1016/j.meatsci.2009.05.013

PACHECO, R. F. Desempenho reprodutivo de fêmeas bovinas de corte no primeiro e segundo ano de 
acasalamento. 2016. Tese (Doutorado em Zootecnia) Universidade Federal de Santa Maria, Santa Maria.

PACHECO, R. F.; MAYER, A. R.; VAZ, M. A. B.; PÖTTER, L.; CATTELAM, J.; CALLEGARO, A. M.; PIZZUTI, L. A.; BRONDANI, I. L.; ALVES FILHO, D. C.; PACHECO, P. S. Qualitative characteristics of meat from cull cows of different genotypes and age class slaughter under different finishing systems: a metaanalytic approach. Anais da Academia Brasileira de Ciências, Rio de janeiro, v. 87, n. 2, p. 1083-1093, 2015. DOI: 10.1590/0001-3765201520140353

PATTEN, L. E.; HODGEN, J. M.; STELZLENI, A. M.; CALKINS, C. R.; JOHNSON, D. D.; GWARTNEY, B. L. Chemical properties of cow and beef muscles: benchmarking the differences and similarities. Journal of Animal Science, Champaign, v. 86, n. 8, p. 1904-1916, 2008. DOI: $10.2527 /$ jas.2007-0478

RESTLE, J.; CERDÓTES, L.; VAZ, F. N.; BRONDANI, I. Características da carcaça e da carne de novilhas charolês e $3 / 4$ charolês $1 / 4$ Nelore, terminadas em confinamento. Revista Brasileira de Zootecnia, Viçosa, MG, v. 30, n. 3, p. 1065-1075, 2001.

RESTlE, J.; FATURI, C.; BERNARDES, R. A. C.; ALVES FILHO, D. C.; MENEZES, L. F. G.; SOUZA, A. N. M.; CARRILHO, C. O. Efeito do grupo genético e da heterose na composição física e nas características qualitativas da carcaça e da carne de vacas de descarte terminadas em confinamento. Revista Brasileira de Zootecnia, Viçosa, MG, v. 31, n. 3, p. 1378-1387, 2002 b.

RESTLE, J.; PASCOAL, L. L.; FATURI, C.; ALVES FILHO, D. C.; BRONDANI, I. L.; PACHECO, P. S.; PEIXOTO, L. A. O. Efeito do grupo genético e da heterose nas características quantitativas da carcaça de vacas de descarte terminadas em confinamento. Revista Brasileira de Zootecnia, Viçosa, MG, v. 31, n. 1, p. 350362, 2002a.

RESTLE, J.; VAZ, F. N.; BERNARDES, R. A. C.; PASCOAL, L. L.; MENEZES, L. F. G.; PACHECO, P. S. Características de carcaça e da carne de vacas de descarte de diferentes genótipos charolês x nelore, terminadas em confinamento. Ciência Rural, Santa Maria, v. 33, n. 2, p. 345-350, 2003.

SANTANA Jr., M. L.; PEREIRA, R. J.; BIGNARDI, A. B.; AYRES, D. R.; MENEZES, G. R. O.; SILVA, L. O. C.; LEROY, G.; MACHADO, C. H. C.; JOSAHKIAN, L. A.; ALBUQUERQUE, L. G. Structure and genetic diversity of Brazilian Zebu cattle breeds assessed by pedigree analysis. Livestock Science, v. 187, n. 1, p. 6-15, 2016. DOI: 10.1016/j.livsci.2016.02.002

ROSE, M. N.; GARMYN, A. J.; HILTON, G. G.; MORGAN, J. B.; VAN OVERBEKE, D. L. Comparison of tenderness, palatability, and retail caselife of enhanced cow subprimals with nonenhanced cow and United States Department of Agriculture select subprimals. Journal of Animal Science, Champaign, v. 88, n. 11, p. 3683-3692, 2010. DOI: $10.2527 /$ jas.2009-2581

ROTTA, I.; OTUKI, M. F.; SANCHES, A. C. C.; CORRER, C. J. Eficácia de antifúngicos tópicos em diferentes dermatomicoses: uma revisão sistemática com metanálise. Revista da Associação Médica Brasileira, Curitiba, v. 58 , n. 3, p. 308-318, 2012. DOI: $10.1590 /$ S0104-42302012000300010

SILVA, V. H.; REGITANO, L. C. A.; GEISTLINGER, L.; PÉRTILLE, F.; GIACHETTO, P. F.; BRASSALOTI, R. A.; MOROSINI, N. S.; ZIMMER, R.; COUTINHO, L. N. Genome-wide detection of CNVs and their association with meat tenderness in Nellore cattle. Plos One, San Francisco, v. 11, n. 6, p. e0157711, 2016. DOI: 10.1371/journal.pone.0157711

SOUZA, M. R.; RIBEIRO, A. L. Revisão sistemática e meta-análise de estudos de diagnóstico e prognóstico: um tutorial. Arquivo Brasileiro de Cardiologia, Rio de Janeiro, v. 92, n. 3, p. 241-251, 2009.

TIZIOTO, P. C.; GROMBONI, C. F.; NOGUEIRA, A. R.; SOUZA, M. M.; MUDADU, M. D.; THOLON, P.; ROSA, N. A.; TULLIO, R. R.; MEDEIROS, S. R.; NASSU, R. T.; REGINATO, L. C. Calcium and potassium content in beef: Influences on tenderness and associations with molecular markers in Nellore cattle. Meat Science, Barking, v. 96, n. 1, p. 436-440, 2014. DOI: $10.1016 /$ j.meatsci.2013.08.001

VAZ，F. N.; RESTLE, J.; QUADROS, A. R. B.; PASCOAL, L. L.; SANCHES, L. M. B.; ROSA, J. R. P.; MENEZES, L. F. G. Características da carcaça e da carne de novilhos e de vacas de descarte Hereford, terminadas em confinamento. Revista Brasileira de Zootecnia, Viçosa, MG, v. 31, n. 3, p. 1501-1510, 2002.

WEBER, M. J.; DIKEMAN, M. E.; JAEGER, J. R.; UNRUH, J. A.; MURRAY, L.; HOUSE, T. A. Effects of feeding a single or sequence of beta-adrenergic agonists on cull cow meat quality. Meat Science, Barking, v. 93, n. 2, p. 275-281, 2013. DOI: 10.1016/j.meatsci.2012.09.004 
